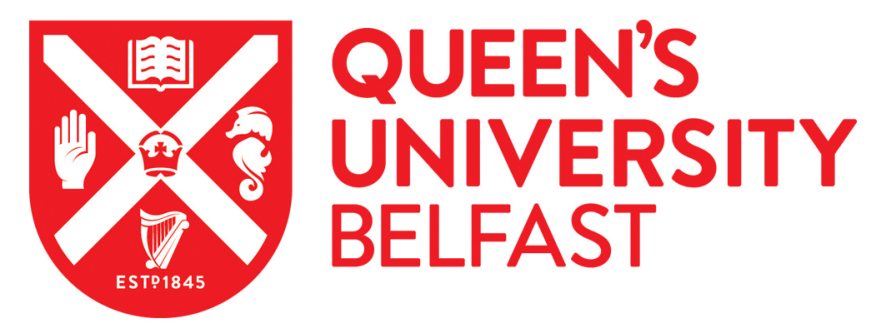

\title{
Reading Dickens Differently
}

Litvack, L. (2020). Reading Dickens Differently: . Wiley-Blackwell.

\author{
Document Version: \\ Other version
}

Queen's University Belfast - Research Portal:

Link to publication record in Queen's University Belfast Research Portal

\section{Publisher rights}

(C) 2020 Johns Hopkins University Press.

This work is made available online in accordance with the publisher's policies. Please refer to any applicable terms of use of the publisher.

\section{General rights}

Copyright for the publications made accessible via the Queen's University Belfast Research Portal is retained by the author(s) and / or other copyright owners and it is a condition of accessing these publications that users recognise and abide by the legal requirements associated with these rights.

Take down policy

The Research Portal is Queen's institutional repository that provides access to Queen's research output. Every effort has been made to ensure that content in the Research Portal does not infringe any person's rights, or applicable UK laws. If you discover content in the Research Portal that you believe breaches copyright or violates any law, please contact openaccess@qub.ac.uk. 


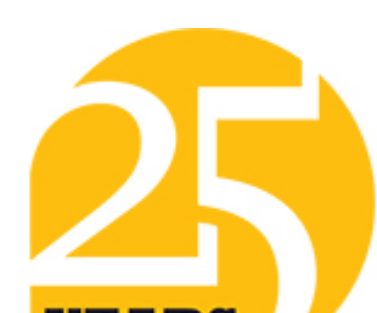

\section{YEARS}

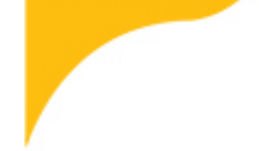

\section{PROJECT MUSE*}

Reading Dickens Differently ed. by Leon Litvack and Nathalie Vanfasse (review)

Lydia Craig

Dickens Quarterly, Volume 37, Number 2, June 2020, pp. 192-195 (Review)

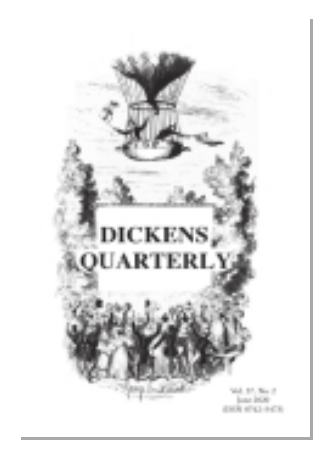

Published by Johns Hopkins University Press

DOI: https://doi.org/10.1353/dqt.2020.0022

$\Rightarrow$ For additional information about this article

https://muse.jhu.edu/article/756617 
finely balanced introductory essay, and you have a Norton Critical Edition destined to earn a place among the major achievements of the series.

David Paroissien

\section{WORKS CITED}

Carlyle, Thomas. The French Revolution: A History. Edited by David R. Sorensen and Brent E. Kinser, Oxford UP, 2019.

[Dickens, Charles.] "The Last Words of the Old Year." Household Words, vol. 2, no. 41, 4 Jan. 1851, pp. 337-39.

Dickens, Charles. The Letters of Charles Dickens. Edited by Madeline House et al., Oxford: Clarendon, 1965-2002. 12 vols.

Forster, John. The Life of Charles Dickens. Edited by A. J. Hoppé, J. M. Dent $\&$ Sons, 1966. 2 vols.

Sutherland, John. "Charles Dickens: A Tale of Two Cities." Who Betrays Elizabeth Bennet? Further Puzzles in Classic Fiction, Oxford UP, 1999, pp. 149-60.

Tomalin, Claire. Charles Dickens: A Life. Viking, 2011.

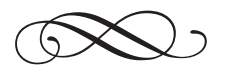

Leon Litvack and Nathalie Vanfasse, editors. Reading Dickens Differently. Wiley-Blackwell, 2019. Pp. xvi + 259. £34.99; \$50.00. ISBN 978-1-11960222-4.

$\mathrm{F}$

or the reader of Charles Dickens considering the manifold possibilities of engaging with his life and novels in the digital age, Reading Dickens Differently is a well-timed and accessible collection. Situating this work as responding to changing circumstances affecting the humanities at large, editors Litvack and Vanfasse chart alterations to forms of public literacy following digital technological innovations and indicate the gradual decline over time of popular cultural interest in Dickens's works. Accordingly, in this volume, they strive "to offer several ways forward, by means of critiques that demonstrate how innovative strategies for reading Dickens differently can excite new generations of literary aficionados" (2). While the argument for melding the alternative strategies of these essays and "traditional interpretative practices of literary studies" might have been fleshed out in clearer detail (2), these strong scholarly offerings signal, in their exciting and meaningful revelations, the extent of what is still to be discovered regarding not merely the study of Dickens in particular but also the wider Victorian age which he has come to epitomize. 
Some minor thematic confusion results from the title, the meaning of which might have been more unmistakably if less elegantly phrased as "Reading Dickens Variously." While new conclusions are reached that inevitably alter previously held misconceptions, the expressed hope for this collection is that it "revitalizes our perception of Dickens and his work, and offers alternative strategies for engaging with a Victorian author and his texts" (9). Though the attractive cover design of Dickens casually taking a selfie backed by the London skyline suggests a compilation exclusively focused on modern technologies, other research focuses abound, in biographical, archival, and theoretical fields. In its multiple perspectives, Reading Dickens Differently encapsulates the wide-ranging influence of the author, whose deep social interest in his own period and impressive linguistic command renders him, at the very least, a translatable and compelling figure in our own.

A pleasing feature of this collection is the inclusion of crystal-clear images throughout, which add greatly to the experience of reading. While the text does not depend upon them to convey meaning, the scans and photographs allow for further investigation of claims by exploring the archival evidence they furnish, especially in Part I: "Reconfiguring Dickens." Exposing John Forster's "reshaping" of the June 1870 events leading to Dickens's burial in Westminster Abbey, Litvack makes a strong case for questioning established accounts concerning circumstances of the author's life and death. Another glimpse of the intersections between Dickens's fraught familial life and his literary output appears in Lillian Nayder's article, which posits in the fraternal doubling of $A$ Tale of Two Cities (1859) striking allusions and parallels to the legal situations surrounding the respective matrimonial debacles of Dickens and his younger brother Fred near initial publication of the serial in All the Year Round.

Exploration of primary sources, a "multi-disciplinary approach" (3), reveals vital new information regarding various aspects of Dickens's influences. Commonly, Thomas Carlyle has been evoked as the most fundamental influence on the author's historicism, but in David Paroissien's telling, historical essayist Thomas Babington Macaulay emerges as a formulative early acquaintance. Using press accounts and prison records, Neil Davies establishes the close attention to ongoing debates regarding incarceration treatment and practices evident in "Pet Prisoners" (1850), illuminating the article's historical inspiration and supplementing the research of Philip Collins into the appearance of prisons in Dickens's fiction.

Dickens's extraordinary linguistic gifts in evoking the readerly imagination are underscored in Part II: "Reincorporating Dickens." Delineating what he calls "a somatic approach to Dickens's fiction" accessible through close reading, Georges Letissier explores the psycho-sensory effects of exposure to Dickensian imagery through empathetic reading, recalling the Pip/Orlick 
confrontation at the limekiln from Great Expectations in one particularly effective example (100). Repeatedly, multiple essays demonstrate Dickens's lasting verbal impact on contemporaries and literary offspring, often absorbed with conscious unwillingness, but undeniable appreciation. D. H. Lawrence's contradictory responses to Dickens's politics, style, and legacy appear in Michael Hollington's essay, which lists several literary devices Lawrence incorporated into his own prose, following Dickens. In Jeremy Tambling's contribution, John Ruskin's dismissal of Dickens's literary merit is seen to waver when exposed to the latter's rhetoric of natural catastrophe, entanglement, and occlusion, so reminiscent of the paintings by J. M. W. Turner admired by both Victorian greats. Chris Louttit disassociates Bleak House (1852-53) from the original illustrations by Phiz, instead examining the text's effect when paired with Fred Bernard's more emotionally evocative illustrations from the Household Edition (1873). Acknowledging the efforts of Phillip Allingham on The Victorian Web, Louttit persuasively insists that the creation of a Visual Dickens Archive would benefit scholars interested in the cultural moment of Dickens's reception and adaptation surrounding each new artistic depiction.

Concluding with Part III: "Resetting Dickens," recent digital and technological innovations are seen as providing new ways to increase enjoyment of Dickens studies. Discussing a series of reading projects enabled by the launch of Dickens Journals Online in 2012, Pete Orford suggests that the delayed gratification of reading Dickens in monthly or weekly instalments leads to "deeper reading" (169). Connecting Dickens's obsession with walking London to the phenomenon of Urban Exploration, Gillian Piggott contrasts his physical and emotional language of navigation with similar expressions by modern day "Urbexers" exploring what they perceive to be their rightful playground. Describing Ubisoft's Assassin's Creed: Syndicate (2015), Francesca Orestano perceives Dickens's important presence in the 1868 storyline as a Neo-Victorian "resuscitation," increasing his cultural influence further (214). Indeed, several of my own students have first encountered Dickens through this game, indicating its inadvertent success in bringing Victorian studies to a new audience.

Although Orestano perceives Dickens's stiff facial movements and overly white teeth in Syndicate as occasioning something of the "authenticity effect" evoked by waxwork depictions of him (214), it should be noted that these are physical aspects typical of both essential and non-player characters in the long-running Assassin's Creed series; they are not explicitly intended to underscore Dickens's appearance as digital simulacra, though he functions as such. Examining A Christmas Carol, a story circulating in cultural motion ever since its 1843 publication, Claire Wood presents Chuck Fischer and Bruce Foster's 2010 pop-up book and interactive iPad app version; the latter 
allows the user to control movement and sound elements, meaningfully heightening the suspense. Now that the popular tale is available as Chained: $A$ Victorian Nightmare, a 2019 Finalist for VR Awards from MWM Interactive, more academic investigations may center on digital adaptation of Dickens's oeuvre.

Online, this volume is easily navigated through Amazon Kindle or the VitalSource Bookshelf, which offers bookmark, flashcard, and emoji features for the reader wishing to record thoughts and emotions inspired by particular sections of the text. Digitally accessible, versatile, and indicative of ongoing shifts in Dickens studies, this is a valuable acquisition for scholars wishing to rethink the boundaries of their own research methodologies and focuses. Dickens's readers will appreciate the indication this collection gives that a more precise history of the author and his increasingly interactive corpus are both waiting to be developed and explored in the twenty-first century.

Loyola University Chicago

Lydia Craig

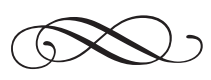

Peter Cook. The Romantic Legacy of Charles Dickens. Palgrave Macmillan, 2018. Pp. xiii + 276. \$64.99. ISBN 978-3-319-96790-5.

$\mathrm{W}$ riting for The Listener in 1954, the critic and writer V. S. Pritchett notes that while Charles Dickens's most obvious literary predecessors were Tobias Smollett and Henry Fielding, "Sterne and the romantic movement have taught [Dickens] the value of pathos, tears, changeableness, and the gestures against an unjust world" (28). Like other critics who have remarked upon Dickens's Romantic inheritance, Pritchett then moves on without much further clarification. These kinds of critical moves leave readers guessing at the connection between the most famous Victorian novelist and the Romantics, such as William Wordsworth, Mary and Percy Shelley, Samuel Taylor Coleridge, William Blake, and John Keats. It is precisely this ongoing gap in the scholarship that Peter Cook attempts to fill in his recent monograph, The Romantic Legacy of Charles Dickens, in which Cook announces he wants "to substantiate the assertion that Dickens was indeed an important legatee of the Romantic movement" (2). Cook's monograph is an important and necessary contribution to the field that should prompt more such scholarship.

Cook's text, however, is not bibliographic detective work; rather he works to find the "parallels, echoes, [and] allusions" between Dickens and the 